\title{
SEBUAH PEMAHAMAN TENTANG SPIRITUALITAS PENDUDUK ASLI BATAK TOBA DAN PENGARUHNYA DALAM KEHIDUPAN SEHARI-HARI
}

\author{
Yohanes Anjar Donobakti*
}

\begin{abstract}
Spirituality is the dynamic motion of total life driven by the Holy Spirit that flows from the depths of the heart of oneself, lead him/her to the true actions and bring to the meaning of life. This definition emerged and formed from the experiences oneself in every moment of his/her lives. Spirituality is always associated with every aspect of life in which he/she lives and works, in situations of joy and sorrow, with what and whom he/she interacts and communicates. Came to realize that the reality of the experience of life and the struggle to form a person's quality of life and character make him/ her having a deep spirituality. Life will be more meaningful when people are aware and recognize that every event and experience the life through the intervention of God in everything around. We can feel the power of God (the Divine) presents and works in every word and action, in every step of the way of our life. Touched, awared and moved by God, the writer realizes that there is a process and a dynamic relation between human reality and divine reality in an indigenious people spirituality. As we have to know that the indigenious people have a spirituality. They see spirituality as a way of life in which all people are free to be themselves and practice life according to their norms. Therefore, this article is a reflection and understanding of the writer about spirituality of indigenious people, especially Batak Toba tribe in North Sumatera.
\end{abstract}

Kata-kata kunci: Penduduk Asli, Spiritualitas, Relasi, Allah, dan Batak Toba.

\section{Pengantar}

Di awal tulisan ini, penulis ingin menyampaikan beberapa hal yang berkaitan dengan beberapa persiapan tentang penulisan tema ini.

\footnotetext{
* Yohanes Anjar Donobakti, Doktor of Philosophy; Southeast Asia Interdisciplinnary Development Institute; dosen tetap pada Fakultas Filsafat Unika St. Thomas, Sumatera Utara.
} 
Pertama: dalam forum ini semua orang menjadi narasumber. Semua orang diundang dan diharapkan untuk mensharingkan penemuan atau wawasan (insight) dan refleksinya atas budaya dan agamanya masingmasing. Kedua: penulis tidak akan membahas semua unsur yang ada dalam penduduk asli Batak Toba, tetapi hanya memfokuskan pada gambaran tentang Allah dan pengaruhnya dalam spiritualitas hidup mereka. Penulis yakin bahwa gambaran tentang Allah juga bisa ditemukan dalam budaya, tradisi, dan agama lainnya. Ketiga: penulis adalah seorang dari suku Jawa, yang sudah hampir 20 tahun tinggal di tanah Batak, Sumatera Utara khususnya di Pematangsiantar. Berdasar pada pengalaman itu, maka dalam artikel ini penulis mencoba menuliskan sebuah pemahamannya tentang spiritualitas penduduk asli Batak Toba terhadap kepercayaan kepada Allah dan pengaruhnya dalam kehidupan sehari-hari.

Metode penulisan artikel ini berdasarkan studi kepustakaan, wawancara, pengamatan dan permenungan penulis sendiri. Dari data kepustakaan, penulis memperoleh beberapa nama penulis tentang adat dan budaya Batak Toba seperti Johannes Warneek, Philip L. Tobing, Anicetus B. Sinaga, Bungaran Antonius Simanjuntak, Togar Nainggolan. Penulis memfokuskan pada tiga nama terakhir.

\section{Penduduk Asli}

Budaya adalah cara hidup suatu masyarakat yang mencakup gagasan, simbol, benda-benda, mencakup aturan, tradisi, dan nilai-nilai yang sangat dihargai dan terus dilestarikan supaya mereka tetap hidup. Struktur masyarakat bervariasi, tergantung pada konsep masyarakat tentang bagaimana mereka harus berhubungan satu sama lain. Mereka mengembangkan konsep dan nilai-nilai yang disesuaikan secara mengagumkan dengan lingkungan mereka. Mereka telah berbagi pemikiran mendalam tentang hal-hal seperti hubungan pribadi manusia dengan Allah, penyesuaian manusia dengan alam, martabat individu, dan hubungan manusia dengan masyarakat. Di dalamnya kita menemukan orang-orang yang penyayang, pengasih, sederhana, ulet, penuh hormat, damai, dan mencintai alam. 
Negara-negara di Asia, termasuk Indonesia, adalah negara yang memiliki sejarah, sosial-budaya, adat-istiadat, tradisi, agama, ekonomi, politik, pendidikan yang kuat dan sangat berpengaruh serta memiliki kontribusi yang sangat besar terhadap pengembangan manusianya. Berdasarkan data dari sensus penduduk yang dilakukan oleh Badan Pusat Statistik (BPS) Republik Indonesia, diketahui jumlah suku di Indonesia yang berhasil terdata adalah sebanyak 1.128 suku bangsa, yang kita kenal dengan penduduk asli, dan suku Batak Toba adalah salah satunya.

Sebagaimana dipaparkan oleh Christian B. Buenafe pada Forum Spirituality yang diselenggarakan oleh Institute of Spirituality in Asia (ISA) di Manila pada tahun 2014, bahwa pada banyak kesempatan, penduduk asli telah diberi label oleh para ilmuwan Barat sebagai penganut animisme dan dipandang oleh para misionaris Barat sebagai penyembah. Mereka juga disebut tidak beradab karena cara berpakaian mereka. Tetapi secara umum, penduduk asli atau masyarakat adat di Asia terikat oleh suatu benang merah: pandangan mereka tentang dunia dan konsep alam semesta. Selanjutnya, ketika seseorang berbicara tentang spiritualitas penduduk asli, ia bertanya-tanya apakah itu agama atau sesuatu yang aneh. Penduduk asli memandang spiritualitas bukan sebagai agama dengan struktur, organisasi dan hierarki tetapi sebagai cara hidup di mana semua orang bebas untuk menjadi diri mereka sendiri dan mempraktikkan kehidupan sesuai dengan norma-norma mereka. Mereka percaya bahwa setiap orang memiliki bakatnya sendiri, dan cara hidup mereka diwariskan oleh pencipta alam semesta. Mereka memandang hidup itu berada dalam kosmik. ${ }^{1}$

Demikian juga spiritualitas hidup penduduk asli Batak Toba sangat berakar pada kosmologi Batak Toba tentang konsep, prinsip, asalusul dan pandangannya tentang dunia. Sebagian besar penduduk suku Batak ini berdiam di provinsi Sumatra Utara. Suku Batak Toba adalah salah satu suku yang ada di Sumatera Utara selain Batak Simalungun, Batak Karo, Batak Mandailing, Batak Angkola, dan Batak Pakpak.

\footnotetext{
${ }^{1}$ Christian B. Beunafe, "Finding and Interpreting Christian Elements in Filipino Spirituality (Towards an Understanding of Images, Symbols, and Rituals in Filipino Christian Spirituality)". Dalam buku yang ditulis oleh Ponce, Rico Palaca and Choudhury, Perla A. (Ed.). Living Flame: A Journal of Interdisciplinary Discource in Spirituality. "Discernment of the Spirit" (Manila: Institute of Spirituality in Asia (ISA). Inc., 2015), hlm. 8.
} 


\section{Spiritualitas Penduduk Asli}

Spiritualitas berkaitan dengan yang suci, Ilahi, transenden, dan hal itu tampak (dan bisa dilihat dan dirasakan) dalam penghayatan hidup manusia dalam dunia nyata. Kees Waaijman mendefinisikan spiritualitas sebagai sebuah proses relasional antara realitas Ilahi dan realitas manusiawi yang membawa kepada transformasi. ${ }^{2}$ Menurut Bishop Labayen, spiritualitas adalah totalitas diri sendiri, proses dan hubungan seseorang dengan orang lain, dengan dunia dan dengan Allah. Dalam definisi tersebut tampak jelas bahwa komponen spiritualitas berkaitan dengan Allah atau yang Ilahi, kemudian bersentuhan dengan realitas dunia nyata (alam ciptaan) dan kesadaran. Bahkan selanjutnya, spiritualitas adalah sebagai suatu pengalaman iman. Sebagai pengalaman iman, spiritualitas memberikan suatu orientasi tertentu pada nilai-nilai seseorang atau kelompok yang menganut dan mempraktikkan keyakinan atau iman yang sama. Nilai-nilai sering diidentifikasikan dengan prinsipprinsip moral dan dalam beberapa hal juga dipengaruhi oleh iman. Oleh karena itu dapat dikatakan bahwa tidak ada nilai-nilai umum tetapi ada etika bersama ditanam di hati setiap orang yang diciptakan oleh Allah. ${ }^{3}$

Spiritualitas penduduk asli juga sangat terkait dengan relasi antar orang atau manusia; dengan demikian, nilai-nilai persatuan, persahabatan dan keramah-tamahan berfungsi sebagai pedoman bagi interaksi manusia dalam hidup sehari-hari. Dan spiritualitas hidup penduduk asli juga sangat terkait dengan tanah; karena tanah menyentuh inti dari keberadaan masyarakat adat. Tanah terikat dengan cara hidup, adat, tradisi, dan agama suku mereka sendiri. ${ }^{4}$

\section{Spiritualitas Penduduk Asli Batak Toba}

Spiritualitas penduduk asli Batak Toba sangat berakar pada kosmologi (konsep, prinsip, asal-usul, pandangan dunia, kisah penciptaan) dan keterkaitannya dengan semua makhluk, serta memiliki

\footnotetext{
2 Kees Waaijman, Spirituality: Forms, Foundations, Methods. Studies in Spirituality Supplement 8 (Leuven - Paris, Dudley, MA: Peeters, 2002), hlm. 312 dan 425.

${ }^{3}$ Christian B. Beunafe, hlm. 6-7.

${ }^{4}$ Christian B. Beunafe, hlm. 9.
} 
sumber tertinggi dari semua kehidupan yaitu Allah. Penduduk asli Batak Toba menyebut Allah sebagai Debata. Allah yang Maha Tinggi (Debata Mulajadi Nabolon) adalah pencipta kosmos dan segala isinya.

Sejak jaman leluhur mereka, orang Batak Toba mempunyai konsep tentang dunia atau alam semesta. Dunia (kosmos) dalam suku Batak Toba dibagi menjadi tiga bagian: Banua ginjang (dunia atas), Banua tonga (dunia tengah), dan Banua toru (dunia bawah). Banua ginjang adalah tempat bersemayamnya Debata Mulajadi Nabolon. Di banua ginjang tinggal juga tiga dewata (dewata natolu) yaitu Batara Guru, Soripada, dan Mangalabulan. Selain dewata natolu, ada juga Dewata Asiasi. Di samping itu masih ada penghuni lain di banua ginjang, mereka berfungsi sebagai utusan Debata Mulajadi Nabolon. ${ }^{5}$ Banua tonga adalah bumi yang dihuni oleh manusia. Banua tonga diciptakan oleh Debata Mulajadi Nabolon melalui Siboru Deak Parujar yang turun dari dunia atas. "Setelah menciptakan segala-galanya, demi mendukung manusia di atas bumi, maka Allah mencipta manusia mulamula sebagai penghuni kayangan, kemudian ditempatkan di atas bumi, di banua tonga........ ditempatkan pada paradis purba, pada bumi perdana....". Tentang banua toru tidak ada kisah mengenai penciptaannya, ia merupakan lautan purba (khaos) yang tak terbatas. Raja atau penguasa banua toru disebut sebagai Si Ular Naga (Naga Padoha Tua). Dialah raja bala, penguasa dan pencipta kenajisan, musibah, penyakit, malapetaka, penderitaan dan sengsara. Dia digelari raja maut dan iblis. ${ }^{8}$ Penghuni banua toru ini harus dihindari oleh manusia dengan mohon pertolongan kepada Allah (Debata). Supaya bisa terhindar dari gangguan si jahat dari banua toru maka mereka membuat ritual, doa dan persembahan.

\footnotetext{
5 Togar Nainggolan, Batak Toba, Sejarab dan Transformasi Religi (Medan: Bina Media Perintis, 2014) hlm. 32.

${ }^{6}$ Togar Nainggolan, ............. hlm. 32.

${ }^{7}$ Anicetus B. Sinaga, Imamat Batak. Menyongsong Katolik (Medan: Bina Media Perintis, 2007), hlm. 37.

8 Anicetus B. Sinaga, .......... hlm. 131; Togar Nainggolan, hlm. 32 .
} 


\section{Kepercayaan kepada Allah dan Pengaruhnya dalam Sipiritualitas Batak Toba}

Menarik bahwa suku Batak Toba percaya kepada Allah (Debata), mengenal dan mempercayai-Nya sebagai Debata Mulajadi Na Bolon, Pencipta manusia, Pencipta alam semesta dan segala isinya. Allah ini secara fisik tak kelihatan (Debata na so tarida) karena berada di kayangan, di dunia atas, di banua ginjang (surga). Roh (Tondi) Allah ada di mana-mana dan di segala sesuatu, seperti pada benda, pohon, binatang, dan juga pada setiap manusia.

Mitos penciptaan mengandaikan bahwa Debata Mulajadi Nabolon sudah ada dari kekal, Raja Mula-mula yang tak bermula, berasal dari yang tak bermula, tak ada akhir; Dialah asalnya dan dia juga yang menjadikan. Tak lain, Dialah Alfa dan Omega Batak. ${ }^{9}$ Debata Mulajadi Nabolon adalah Allah yang patut disembah, dan dimohon pertolongan oleh manusia di banua tonga supaya hidup manusia selamat dari gangguan si jahat dari banua toru, serta memohon keberhasilan usaha dalam mengolah tanah untuk tanam-menanam sehingga mereka dapat melangsungkan kehidupan di dunia. Pernyataan tersebut tampak dalam doa agung yang diucapkan oleh Raja Sisinga Mangaraja, singkat doanya sebagai berikut: "Ya Ompung Mulajadi Nabolon, Engkaulah yang menjadikan segala yang ada. Engkaulah yang menjadikan manusia. Engkaulah yang menjadikan mata agar dapat melihat. Engkaulah yang menjadikan telinga agar dapat mendengar..... Inilah permohonanku ya Ompung, beras sakti yang memberikan ketenangan ini..... baiklah kami sepakat dan saling menyetujui, agar turun hujan yang menggemburkan tanah, yang menyuburkan tanam-tanaman, yang mengembang-biakkan ternak, yang menghidupkan manusia". ${ }^{10}$

Leluhur penduduk asli Batak Toba mempunyai tempat pemujaan atau tempat suci untuk menyembah Debata Mulajadi Nabolon. Tradisi penyembahan ini terdapat dalam ritus agama asli Batak Toba (Parmalim). Kelompok dan pratik agama Parmalim ini sekarang masih bisa di temukan di daerah Batak Toba (misalnya di Huta Tinggi,

\footnotetext{
${ }^{9}$ Anicetus B. Sinaga, .......... hlm. 131.

${ }^{10}$ Anicetus B. Sinaga, ........ hlm. 81-83.
} 
Laguboti - Porsea). Sekarang, orang Batak Toba juga sudah banyak yang menjadi Kristen Protestan atau Kristen Katolik. Gambaran tentang Allah Kristiani diterima dan dipercayai oleh orang Batak Toba sebagai Allah Yang Mahatinggi, Pencipta segala sesuatu. Iman dan kepercayaan orang Batak Toba yang Kristiani kepada Allah itu sangat mempengaruhi spiritualitas mereka hidup sehari-hari, hal itu dapat dilihat dan dirasakan dalam:

a. Seni Musik (Gondang): Gondang Alu-alu (tersirat di dalamnya ucapan syukur kepada Allah) Gondang Somba (menyembah kepada Allah), Gondang Mula-mula (memohon ijin kepada Allah dan kepada semua yang hadir), dan Gondang Malim (menyembah kepada Allah) yang sering dibuat dalam pesta-pesta adat. Catatan: Musik yang diperuntukkan kepada Allah mempunyai suara khas, dan ketika menari, penari memiliki posisi tangan yang khas dan tak boleh ada gerakan tubuh selama musik berbunyi.

b. Seni Tari: Tarian yang diiringi dengan gondang (alat musik orang Batak Toba) juga dipakai dalam perayaan Liturgi Kristen Katolik (misalnya lagu Tuhan Kasihanilah Kami, Kemuliaan, Kudus, dan Anak Domba Allah dan persembahan).

c. Bangunan rumah adat, makam/kuburan, dan gereja menggambar kosmos yang terdiri dari tiga dunia: Atas, tengah, dan bawah.

Gambaran Allah dan relasinya dengan manusia dalam konsep penduduk asli dan mayarakat Batak Toba dapat dilihat dan digambarkan sebagai berikut:

\begin{tabular}{|c|c|}
\hline $\begin{array}{c}\text { Konsep Kosmos } \\
\text { Batak Toba }\end{array}$ & $\begin{array}{c}\text { Konsep Rumah Adat } \\
\text { Batak Toba }\end{array}$ \\
\hline $\begin{array}{c}\text { Banua Ginjang } \\
\text { Dunia Atas } \\
\text { (Tempat Allah Yang Maha Tinggi) }\end{array}$ & \\
\hline $\begin{array}{c}\text { Banua Tonga } \\
\text { Dunia Tengah/Bumi } \\
\text { (Tempat Manusia) }\end{array}$ & \\
\hline & \\
\hline
\end{tabular}




\section{Marga dan Sistem Kekerabatan dalam Adat Batak Toba}

Menurut mitos tentang asal-usul penduduk asli Batak dikatakan bahwa nenek moyang mereka adalah seorang putri kayangan Siboru Deak Parujar yang menikah dengan Raja Odapodap yang berasal dari kayangan juga. Mereka melahirkan Raja Ihatmanisia dan Boru Itammanisia. Dari mereka muncul nama Raja Miokmiok, Eng Banua, Raja Bonangbonang. Dari keturunan Raja Bonangbonang ini lahirlah Raja Batak. Raja Batak yang tinggal di kaki gunung Pusuk Buhit Samosir mempunyai dua putera yaitu Guru Tateabulan dan Raja Isombaon. Nama kedua putera ini menjadi nama dari dua kelompok besar marga suku Batak, yaitu Lontung dan Sumba. Dari kedua kelompok marga ini lahirlah marga-marga Batak. ${ }^{11}$ Kedua kelompok ini merupakan induk marga-marga Batak. Dari kedua orang atau kelompok ini berkembang marga-marga yang terdapat di tengah-tengah masyarakat Batak. $^{12}$

Semua orang Batak mempunyai marga. Marga menunjukkan asal keturunan, satu nenek moyang. Marga (nama marga) orang Batak mengikuti garis keturunan ayah. Status sosial dalam masyarakat sangat ditentukan oleh marga. Dalam hubungan sosial orang Batak, marga merupakan dasar untuk menentukan partuturan, hubungan persaudaraan, baik untuk kalangan semarga maupun dengan orang-orang dari marga yang lain. Selain itu marga juga menentukan kedudukan seseorang di dalam masyarakat yang teratur menurut pola dasar pergaulan dan kekerabatan. Mengapa, karena dengan mengetahui marga seseorang maka setiap orang Batak akan lebih mudah untuk mengetahui asal-usul keluarganya dan hubungan sosial di antara mereka. ${ }^{13}$ Contoh, bila salah seorang Batak Toba berjumpa dengan orang Batak Toba yang lain di suatu tempat, di perjalanan, atau di perantauan maka dalam percakapan mereka ada kesempatan berkenalan. Orang pertama bertanya, marga apa kamu? Bila orang kedua menjawab, marga Sinaga. Dan jika orang

\footnotetext{
11 Tigor Nainggolan, .............. hlm. 56-57.

12 Bungaran Antonius Simanjutak, Struktur Sosial dan Sistem Politik Batak. Toba Hingga 1945.

Suatu Pendekatan Antropologi Budaya dan Politik. (Jakarta: Yayasan Obor Indonesia, 2006), hlm. 78-79.

${ }^{13}$ Bungaran Antonius Simanjuntak, hlm. 80-81.
} 
pertama juga bermarga Sinaga maka mereka langsung akrab dan dekat. Karena mereka berdua bersaudara meski ayahnya berbeda, tapi ayah mereka mempunyai marga yang sama. Tali persaudaraan mereka semakin kuat karena mereka masih satu marga dan satu keluarga. Ada roh (tondi) atau spirit yang menyatukan mereka bahwa mereka berasal dari satu garis keturunan yang sama. Spirit itulah yang menjadi spiritualitas hidup yang dipelihara dan dihidupi oleh orang Batak Toba sampai sekarang.

Manusia Batak Toba adalah ciptaan Allah, berasal dari Allah. (Catatan: Tondi Allah ada dalam diri manusia). Tondi yang ada pada manusia Batak diterima dari nenek moyang mereka menurut garis lurus marganya masing-masing. Nenek moyang mereka menerima Tondi dari dunia atas, dari Allah sendiri. Mereka menyadari realitasnya sebagai ciptaan Allah, berasal dari keturunan raja (dari atas), dan memperoleh nama marga yang sangat berarti bagi dirinya, keluarganya, dan kedudukannya dalam masyarakat, serta terutama dihadapan Allah. Sadar akan siapa dirinya, maka orang Batak Toba selalu bersyukur dan berdoa kepada Allah, menyembah dan memuji kebaikan Allah, mohon ampun atas dosa, serta memohon berkat dan anugerah Allah bagi kehidupannya sehari-hari. Spiritualitas orang Batak Toba dalam relasinya dengan Allah dapat dilihat dan dirasakan terutama:

a. Dalam keluarga, orang tua selalu meminta anak-anaknya, seluruh anggota keluarganya untuk selalu ingat akan Allah dengan berdoa, ke gereja, dan bersyukur sebagai ungkapan iman dan kepercayaan yang tinggi kepada Allah sumber hidup dan tujuan akhir hidup manusia. Orangtua, terutama ayah atau pamannya (Tulang) sangat dihormati dan ditaati oleh anak-anaknya. Mereka dianggap sebagai Allah yang kelihatan (Debata na tarida) dalam lingkup keluarga. Contoh: pada pesta tahun baru. Pada peristiwa itu spiritualitas Batak Toba benar-benar nyata dan hidup.

b. Pada pesta adat atau keagamaan, misalnya kelahiran, pembaptisan, perkawinan, dan kematian selalu dikaitkan dengan Allah melalui doa, ucapan syukur, dan permohonan.

Penduduk asli Batak Toba sangat menjungjung tinggi keluarga dan adat budaya. Keluarga orang Batak Toba sangat terkait erat dengan 
marga dan adat budaya yang kental. Ayah mempunyai kedudukan yang sentral dan berpengaruh karena membawa nama marga bagi keluarga (isteri dan anak-anaknya) dan bagi masyarakat adat. Leluhur orang Batak Toba menciptakan aturan dan sistem adat dalam hidup bermasyarakat yaitu Dalihan Natolu. Dalihan Natolu artinya tungku yang terdiri (disangga) tiga penyangga (tiang) yang saling membutuhkan antara satu dengan yang lainnya. Sistem Dalihan Natolu ini mencipta hubungan sosial yang lebih erat dan mesra antar marga orang Batak dalam kehidupan sehari-hari. Dalihan Natolu tersebut adalah Hula-hula, Boru, dan Dongan Sabutuha. Hula-hula adalah pemberi isteri (mempelai wanita), boru adalah penerima isteri, dan dongan tubu adalah teman semarga (Nainggolan 2014:69). Dalihan Natolu yang di banua tonga ini merupakan "copy”an dari Dewata Natolu yang ada di banua ginjang dimana Batara Guru sebagai hula-hula, Soripada sebagai boru, dan Mangalabulan sebagai dongan tubu (Togar Nainggolan).

Dalam struktur Dalihan Natolu, golongan hula-hula (pemberi isteri) merupakan golongan yang sangat dihormati dan tinggi kedudukannya dalam pandangan rohani maupun jasmani. Dikatakan bahwa hula-hula adalah Allah yang terlihat (Debata na tarida). Dia sebagai pemberi dan sumber hidup bagi boru (Nainggolan 2014:69). Sebagai pemberi isteri, golongan ini dianggap mempunyai kekuatan magis untuk melimpahkan pasu-pasu (berkat/anugerah roh) atau sahala (kekuatan rohani) kepada golongan penerima isteri. Itulah yang disebut Tondi yang datang dari Allah yang dicurahkan turun-temurun melalui nenek moyangnya kepada hula-hula dan kepada anak-anaknya (dan boru-nya) atau keturunannya. Hula-hula boleh meletakkan tangan ke atas kepala pihak boru dan kelompoknya, tetapi sebaliknya tidak boleh dilakukan bahkan pantang atau tabu. Hula-hula merupakan sumber kekuatan supernatural yang dapat memberi semangat kepada boru. ${ }^{14}$ Maka tepat sekali ungkapan somba marhula-hula, maksudnya bahwa orang-orang yang termasuk kelompok parboru harus hormat dan menyembah hula-hula mereka. Contoh, ketika pesta pernikahan, ada acara 'mangalap tondi' (mengambil roh), dimana pada waktu itu pengantin datang dan menyembah sambil memberikan persembahan

\footnotetext{
${ }^{14}$ Bungaran Antonius Simanjuntak, ........... hlm. 102-103.
} 
daging babi (tudu-tudu sipanganon) kepada hula-hula. Tujuan dari menyembah ialah supaya hula-hula memberikan 'tondi', pasu-pasu, atau sahala kepada puterinya dan menantunya (hela), dengan harapan supaya mereka mendapat keturunan (anak-anak) yang baik, sehat, dan sukses. Kemudian hula-hula memberi ikan (mangupa boru) sebagai upah kepada boru-nya supaya tondi boru-nya dan hela-nya kuat. Karena tondi boru perlu kuat untuk memperoleh keturunan dan selamat.

Boru atau Parboru yaitu kelompok penerima isteri. Kepada mereka ini, yaitu suami dan marga yang semarga dengan suami, hendaklah bersifat membujuk dan mengayomi. Sikap dan prinsip ini dikenal dengan elek marboru (boru harus disayangi).

Sedangkan Dongan Tubu atau Dongan Sabutuha merupakan kelompok marga (biasanya satu marga) yang mempunyai satu nenek moyang. Dongan tubu artinya saudara-saudari sedarah, satu ibu. Sikap dan perhatian mereka dengan sesama semarga dikenal dengan ungkapan manat mardongan tubu. Tujuannya supaya terhadap sesama marga hendaklah selalu hati-hati, tidak sembarangan terhadap saudara perempuan dan suaminya. Mereka harus saling menghormati dan mencintai, dan respek satu sama lain.

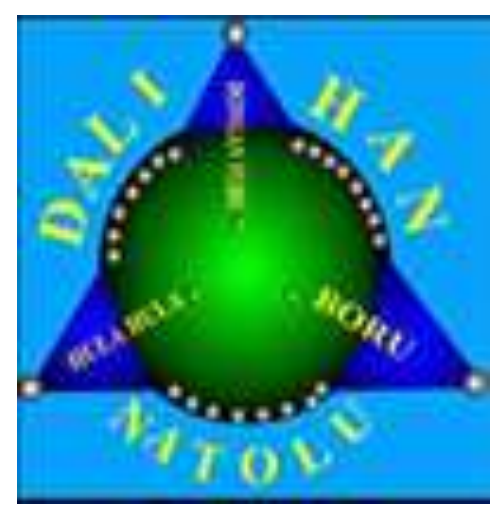

Ketiga unsur dalam Dalihan Natolu tersebut merupakan unsur yang saling mendukung, melengkapi, mempersatukan, dan menguatkan relasi dan komunikasi antar marga atau kelompok dalam ikatan kekerabatan dan persaudaraan dalam keluarga dan masyarakat baik secara adat/sosial maupun keagamaan. Dalam acara adat setiap orang Batak Toba akan berperan menjadi salah satu dari Dalihan Natolu itu. Siapa sebagai hula-hula, siapa sebagai boru, dan siapa sebagai dongan tubu tergantung pada acara adat yang sedang dilaksanakan, misalnya pada pesta adat seperti perkawinan atau kematian.

Ungkapan somba marhula-hula, elek marboru, dan manat mardongan tubu adalah falsafah hidup orang Batak Toba yang sangat 
berpengaruh pada kehidupan sosial dan spiritual. Mengapa spiritual, karena hal tersebut telah menjadi spiritualitas hidup masyarakat Batak Toba dalam kehidupan sehari-hari. Dalam peristiwa apapun baik pesta adat maupun keagamaan, spiritualitas tersebut hidup dan menjadi penggerak atau roh (spirit) setiap orang Batak Toba dalam berelasi dengan sesama dan dengan Allah. Somba, manat, dan elek yang terungkap dan dipraktikkan dalam adat Dalihan Natolu tersebut adalah sikap dan perbuatan positif, menyenangkan, dan bersumber pada kasih. ${ }^{15}$

\section{Penutup}

Berdarasarkan pemaparan di atas tentang mitos penciptaan, asal mula marga Batak Toba dan keturunannya, serta adat budaya Batak Toba yang kita kenal dengan Dalihan Natolu, penulis mencoba menarik garis benang merah tentang siapa Allah dan bagaimana pengaruhnya bagi spiritualitas penduduk asli Batak Toba. Spiritualitas itu terungkap dalam relasi mereka yang dinamis dengan Allah, sesama, dan alam semesta/kosmos. Mengacu pada definisi spiritualitas menurut Kees Waaijman dan Bishop Labayen di atas, maka dalam hidup sehari-harinya orang (penduduk) asli Batak Toba, sejak jaman leluhurnya sampai sekarang, telah terjadi relasi dan terus menjalin relasi dengan Allah. Proses relasional ini dipahami sebagai proses interiorisasi yang intensif, memurnikan, dan menyatukan antara tradisi dan kehidupan batin. Dan model atau cara-cara mereka dalam mengasah rohani (spiritual) lewat segala aktifitas merupakan jalan pemurnian diri seseorang (kecerdasan, kemauan, dan ingatan) dan pembentukan perilaku seseorang. ${ }^{16}$

Dari pengalaman yang sudah sekian kali menghadiri dan mengikuti pesta adat dan keagamaan, penulis melihat dan merasakan sendiri akan kehadiran Allah yang agung, sakral, dan indah dalam hal-hal yang berkaitan dengan Allah baik melalui musik, tarian, simbol, ritual, dan adat dan budaya orang Batak Toba. Penulis (atau siapa saja) bisa tersentuh oleh kehadiran Allah yang indah dan mengagumkan (dengan mengatakan wow......) yang hadir dalam bentuk doa, tarian, nyanyian, bangunan, pesta adat atau ritual keagamaan (Katolik) yang diungkapkan

\footnotetext{
${ }^{15}$ Richard Sinaga, Meninggal, Adat Dalian Natolu (Jakarta: Dian Utama, 1999), hlm. 21.

${ }^{16}$ Kees Waaijman, .............. hlm. 364.
} 
dan dilakukan oleh orang Batak Toba. Pengalaman tersebut membawa dan mengangkat penulis (siapa saja) kepada pengalaman akan Allah, perjumpaan dengan Allah, dan akhirnya sampai pada suatu kesadaran (tersadar) bahwa Allah ada dan hadir (dengan mengatakan oooo.....). Setelah tersentuh dan tersadar, orang tergerak (dari dalam hati) untuk memberi respon positif dan ikut berpartisipasi aktif dalam aktifitas yang sedang terjadi (dalam pesta adat atau keagamaan) misalnya dengan menyanyi, menari, atau ia sendiri sampai meneteskan air mata karena bahagia, kagum dan terharu. Karena sudah tersentuh, terdasar, dan tergerak hatinya oleh Allah yang hadir, menyapa, dan mencintai maka orang tersebut mengalami transformasi spiritual. Transformasi itu terjadi dalam perubahan hidup setiap pribadi ke arah yang lebih baik dan berkenan kepada Tuhan dan sesama. Hal itu tampak dalam sikap dan perilaku yang baik dalam hidup sehari-hari.

Demikian pemaparan penulis dalam usaha untuk memahami gambaran Allah dan pengaruhnya dalam spiritualitas penduduk asli Batak Toba. Dari sekilas pemaparan di atas dapat kita lihat dan rasa-kan bahwa orang atau masyarakat Batak Toba dan keturunannya masih melestarikan spiritualitasnya dengan baik dalam kehidup sehari-hari. Relasi yang dinamis antara realitas Allah (Debata Mulajadi Nabolon) dan realitas manusia orang Batak Toba terus dihidupinya dalam setiap aktifitas baik secara pribadi, keluarga, dan masyarakat dalam usahanya untuk mencapai suatu hidup dan kehidupan yang lebih baik, kudus, indah, harmonis, penuh semangat, dan hidup dalam sukacita di dunia ini (banua tonga) hingga saatnya nanti kembali kepada Allah di banua ginjang. Spiritualitas hidup yang dipraktikkan dan dihayati oleh penduduk asli Batak Toba telah membentuk sikap dan perilaku mereka.

Iman dan kepecayaan kepada Allah (Debata Mulajadi Nabolon) yang diungkapkan oleh penduduk asli Batak Toba dan kini masih diteruskan hingga sekarang itu sungguh menunjukkan spiritualitas hidup yang nyata dalam kehidupan mereka sehari-hari. Harapan penulis, semoga para pembaca (pendengar) semakin mudah tersentuh, tersadar, tergerak oleh Allah, dan mampu melihat, merasakan, dan mengalami kehadiran Allah yang agung dan mengagumkan dalam setiap spiritualitas 
yang dimiliki dan dihidupi oleh setiap penduduk asli di manapun mereka berada.

$===0000====$ 


\section{DAFTAR PUSTAKA}

Buenafe, Christian B. "Finding and Interpreting Christian Elements in Filipino Spirituality (Towards an Understanding of Images, Symbols, and Rituals in Filipino Christian Spirituality)". Dalam buku yang ditulis oleh Ponce, Rico Palaca and Choudhury, Perla A. (Ed.). Living Flame: A Journal of Interdisciplinary Discource in Spirituality. "Discernment of the Spirit". Manila: Institute of Spirituality in Asia (ISA). Inc., 2015.

Nainggolan, Togar. Batak Toba, Sejarah dan Transformasi Religi. Medan: Bina Media Perintis, 2014.

Simanjuntak, Bungaran Antonius. Struktur Sosial dan Sistem Politik Batak Toba Hingga 1945. Suatu Pendekatan Antropologi Budaya dan Politik. Jakarta: Yayasan Obor Indonesia, 2006.

Sinaga, Anicetus B. Imamat Batak Menyongsong Katolik. Medan: Bina Media Perintis, 2007.

Sinaga, Richard. Meninggal, Adat Dalian Natolu. Jakarta: Dian Utama, 1999.

Waaijman, Kees. Spirituality: Forms, Foundations, Methods. Studies in Spirituality - Supplement 8. Leuven - Paris, Dudley, MA: Peeters, 2002.

\section{Wawancara:}

1. Pastor Dr. Togar Nainggolan OFMcap. Tinggal di Biara Kapusin Kamerino Nagahuta Pematangsiantar, Sumatera Utara. 24 Februari 2019.

2. Bapak M. Marsoit. Tokoh adat. Tinggal di Jl. Pertamina/Jln. Tanjung Pinggir No. 16 Pematangsiantar, Sumatera Utara. 24 Februari 2019.

Artikel ini sudah pernah dipresentasikan oleh penulis dalam International Joint Conference, Doing Theology in the Contemporary Indonesia Interdisciplinary Perspectives, yang di selenggarakan oleh badan kerjasama antara AFTI (Asosiasi Filsafat Teologi Indonesia, AAFKI (Asosiasi Ahli Filsafat Keahlian Indonesia), AsTeKia (Asosiasi Teolog Katolik Indonesia) dan Sekolah Tinggi Teologi - Pontifical Fakultas Teologi Wedabahti - Universitas Sanata Dharma di Gedung Paskasarjana Fakultas Teologi Universitas Sanata Dharma, Kentungan, Yogyakarta pada tanggal 1 - 2 Maret 2019. 